International Journal of Engineering \& Technology, $7(2.29)(2018) 1147-1150$
International Journal of Engineering \& Technology
SPC
Website: www.sciencepubco.com/index.php/IJET
Research paper

\title{
Sovereignty of A Nation: A Lesson Learnt From the Case of Batu Puteh Island (Pedra Branca)
}

\author{
1,2,3,4,5,6,7,8,9,13,14 Universiti Tun Hussein Onn Malaysia \\ 10Universiti Utara Malaysia \\ 11 Universiti Malaysia Kelantan \\ 12Universiti Malaysia Kelantan \\ *Corresponding author E-mail: khairula@uthm.edu.my
}

Khairul Azman Suhaimy ${ }^{1 *}$, Lutfan Jaes ${ }^{2}$, Khairol Anuar Kamri ${ }^{3}$, Hussain Othman ${ }^{4}$, Shah Rul Anuar Nordin ${ }^{5}$, Zahrul Akmal Damin ${ }^{6}$, Harliana Halim ${ }^{7}$, Mohd Hisyam Abdul Rahim ${ }^{8}$, Abdul Shakor Borham ${ }^{9}$, Mohd Fuad Othman $^{10}$, Marwan Ismail ${ }^{11}$, Mohd Zain Mubarak ${ }^{12}$, Najah Ramlan ${ }^{13}$, Hani Suraya Aziz ${ }^{14}$

\begin{abstract}
This paper discusses on the issues related to Batu Puteh Island (Pedra Branca) which is a topic of discussion in relation to the sovereignty of a country and its implications in the future. Losing territories will undermine the sovereignty of a country and is an insult to them. The reality is a bitter truth. Sovereignty is a symbol of power to many countries. The corresponding letter by the Acting Secretary of Johore dated $21^{\text {st }}$ September 1953 stated that Johore does not claim ownership of Pedra Branca. The letter was seen by ICJ as a sign that Johore had handed over its sovereignty on Batu Puteh Island over to the British. Therefore, the court concluded that the letter clearly indicates that since 1953, Johore has declared that it no longer had sovereignty over Pedra Branca. Various questions arise regarding the letter. Where is the authority and sovereign of the Sultan of Johore who ruled over Johore and its territories? Can an Acting Secretary of State legitimately decide on matters of sovereignty, land and territorial rights? Or, should it be decided by the Sultan as head of a sovereign state? These are some of the questions which are yet to be answered and documentation is vital. It will determine the future and the road to success. Learn from history, learn from the administrative weaknesses and individual mistakes, and remember that history repeats itself in the future. Our own mistakes cost us an island which was originally ours for centuries. Our absent mindedness led us in losing the island's sovereignty to other nation. Everyone knows that the island belongs to Johore with all related documents are complete and history has proven it. Always be careful when making any decisions or be sorry for life.
\end{abstract}

\section{Introduction}

Sovereignty is a symbol of power to many countries. It is very important to defend the supremacy and independence of a country to deter continuous colonisation. In this challenging globalisation era, sovereignty is often an issue especially to maritime countries. In the Malaysian context, sovereignty plays a big role in keeping the country safe against external threats and being respected by others.

National security is also closely related to soverignty of a country. The people's role in defending the sovereignty of the country is important to allow the unwavering obedience as to ensure national security. Furthermore, this role is imperative in the effort to bring a more solid concept of unity towards building a strong nation. As an important aspect of a country, sovereignty can be easily affected by the leader's negligence and failure to conduct effective negotiations. Weaknesses in terms of state administration and signed agreements often cause some countries to be oppressed and deprived of their sovereignty. All parties including the people and the state leaders must learn from history in order to understand other countries' bad tactics and be careful in making any decisions to ensure that the future generations will not suffer losses and misery due to wrong decisions.
A country's history and development are very much interrelated with one another, especially regarding its future. From history, a country can learn to improve their past mistakes, as the Malay saying goes, "Yang baik jadikan teladan, yang buruk jadikan sempadan (Adopt anything that is good and leave the bad things on the other side)". Hence, leaders of a country should learn about history for the sake of the younger generation and the nation. This is the basic in building a well-established nation in terms of aspirations, philosophy, achievements and brilliant future.

History will forever be the basis in the development of a nation as mentioned by George Santana in (1), "Those who did not learn from the past are doomed to repeat it". Repeating the same mistakes can ruin the life of an individual, the society and the country. Therefore, accurate planning and effort is necessary to overcome and exit from the crisis of the past. Despite the efforts made, everything will always be subjected to the mercy and power of the Almighty. History is the best available teacher. History is a compilation of various past stories - events and phenomena, which can be learnt from by the younger generation. Humans highly value their own history and are incapable of forgetting it. History, according to an American historian, is like driving a car by looking in the rearview mirror (2).

Carr (3) definition of history showed that history serves as an archive to continue collecting the experiences from one generation 
to another, and thus leads to ongoing process of enculturation, socialisation and education. Consequently, history has great value and importance to individuals, communities and nations. Collections of past events or history can guide and teach us about life's challenges and difficulties. We must be aware of the reality of life and act accordingly to overcome it. Therefore, history is important as an indicator to the individual, the community and the country to handle current and future situations effectively and with confidence.

\section{Definitions and Characteristics of Sover- eignty}

The idea of sovereignty was first introduced by Jean Bodin, a French scholar, in his book 'Six Books of the Commenwealth'. He was living in the time when the countries were increasingly growing and the king had the absolute authority of ruling the nation ('supreme'). The context then changed to 'statehood' and later slowly changed towards a higher degree of power or 'sovereignty' (informasiana.com, 2016).

The characteristics of sovereignty according to Jean Bodin can be summarised as follows:

i. Original, not handed down by any other power whether from within or outside of the country,

ii. The highest, there is no other higher authority that can limit its power,

iii. Permanent, the power of the state goes on continuously without intervention even when the government, the leaders and the order of the state change,

iv. Indivisible since there is only one supreme power,

v. Non transferable to another body, either in the form of submission or discharge.

(Taken from informasiana.com, 2016; seputarilmu.com, 2016) Sovereignty plays an important role for the younger generation who will lead the country in the future. They can lead and govern the country freely without any restrictions or control from other countries. Sovereignty also enables them to expand the country in all fields without being manipulated by leading nations with hidden agenda. The younger generation will also be capable of defending our national resources and heritages as well as avoiding domination and colonisation of foreign countries.

\section{Background and Dispute}

Batu Puteh Island (Pedra Branca) has a total area of 0.2 hectares; about $12.8 \mathrm{~km}$ from Pengerang, Johore and $46 \mathrm{~km}$ from Singapore. Initially, the Sultanate of Johore had the rights of Batu Puteh Island but handed it over to the British to handle Horsburgh Lighthouse since the mid $19^{\text {th }}$ century. There are two coral reef areas; the first one is known as the Middle Rocks, located $1.1 \mathrm{~km}$ south of Batu Puteh Island, and the second one is known as the South Ledge which was naturally formed rocks which is visible only during low tide in a distance of $3 \mathrm{~km}$ from the Middle Rocks and 4 $\mathrm{km}$ to the south Batu Puteh Island. The claim of Middle Rocks and South Ledge were made by Singapore in 1993, 13 years after the claim on Batu Puteh Island was made (4).

\section{Findings}

The territorial dispute over Batu Puteh Island has lasted for 28 years, causing both Malaysia and Singapore to agree to bring this conflict to the International Court of Justice (ICJ) in 1993. The Acting President of ICJ, Judge Awn Shawkat Al-Khasawneh, when reading the overlapping claims, said that the status of sovereignty over Batu Puteh Island was decided by a majority of $12-4$ judges to Singapore while a majority of $15-1$ judges agreed on the status of the Middle Rocks (located about $1.1 \mathrm{~km}$ to the south of Batu Puteh Island) to Malaysia. Another maritime feature, the
South Ledge, will belong to the country which owns the territorial waters nearest to the location (4).

The passing of sovereignty of Batu Puteh Island, which is historically the property of the Sultanate of Johore, was decided by the ICJ based on the corresponding letter by the Acting Secretary of Johore dated $21^{\text {st }}$ September 1953, which stated that Johore does not claim ownership of Pedra Branca, the Portugese name for Batu Puteh Island. The reply was not only related to the lighthouse but the island as a whole. When the letter was read in the Singapore context about the status of Batu Puteh Island, it was proven that the letter is addressing the issue of the island sovereignty. "Therefore, the court concluded that the letter clearly indicates that since 1953, Johore has declared that it no longer had sovereignty over Pedra Branca (Batu Puteh Island)," said Shawkat who chaired the ICJ conference to decide on the overlapping claims on Batu Puteh Island, Middle Rocks and South Ledge (4).

The ICJ takes into accounts and primarily focusing their judgment on the corresponding letter by the Acting Secretary of Johore dated $21^{\text {st }}$ September 1953. The letter which stated that Johore did not claim Pedra Branca ownership was seen by ICJ as a sign that Johore had handed over its sovereignty on Batu Puteh Island over to British. This means, since 1953, Johore has lost Batu Puteh Island. ICJ judgment also touched on the issue of six official Malaysia maps published between 1962 and 1974 with Singapore labelled as the owner of Batu Puteh Island. According to ICJ, indirectly, this strengthen the Singapore claim over Batu Puteh Island since no maps were published showing Batu Puteh Island as Malaysian territory (4)

However, ICJ confirmed that Batu Puteh Island belonged to the Johore government based on the historical point of view and the application of international law in reference to other cases like Eastern Greenland and Island of Palmas. Batu Puteh Island was originally under the sovereignty of the Johore government. In addition, the ICJ also recognised and took into account the role of Sea Gypsies who benefitted from the island and nearby locations for their economic activities, and their affiliation with the Sultan of Johore. ICJ therefore denied Singapore's claim that Batu Puteh Island was 'terra nullius' (land belonging to no one) before 1847 and was not acceptable as an argument (4). It is in line with Malaysia argument that '... (to say) Batu Puteh Island is without owner is (actually) vague' (5).

Batu Puteh Island cannot be defended as 'terra nullius' (land belonging to no one) since in the meantime, the island was referred to in the preliminary map as a sea marker and a dangerous point area. "Even the Portuguese publications stated that the indigenous people use this island as early as 1552 , and in 1862 , including the statement by the British Resident in Singapore, John Crawfurd, who stated that sea gypsies had inhabited the island area under the Sultanate of Johore". In fact, Singapore Free Press also confirmed that the island belonged to Johore in a report on the construction of a lighthouse on Batu Puteh Island (5).

\section{Questions}

There are a few questions regarding the passing of Batu Puteh Island to Singapore, such as:

Question One: The letter signed by the Acting Secretary of Johore (M. Seth bin Saaid) dated $21^{\text {st }}$ September 1953. Where is the authority and sovereign of the Sultan of Johore who ruled over Johore and its territories?

Question Two: Can an Acting Secretary of State legitimately decide on matters of sovereignty, land and territorial rights? Or, should it be decided by the Sultan as head of a sovereign state?

Question Three: Was the letter dated $21^{\text {st }}$ September 1953 received a royal assent by the Sultan of Johore or was the decision made influenced by any particular parties in this regard?

Question Four: From the point of view of the constitution, the Johore Treaty 1914 and the Federation of Malaya Agreement 1948 have stated that all the rights and authority regarding Johore foreign affairs were transferred to the British and enforced through by the Federal Commissioner. The Federal Commisioner was 
appointed under the consent of His Majesty while the two agreements were valid until 1957 when the Federation of Malaya Independence Act 1957 commenced to run. Thus, the letter issued had contradicted the Johore Treaty 1914 and the Federation of Malaya Agreement 1948 which valid until 1957 (5). The final judgment made did not take into consideration the previous agreements made thus far. Therefore, the letter dated $21^{\text {st }}$ September 1953 which became the proof for Singapore to gain sovereignty over Batu Puteh Island, must be re-examined and application for revision of judgment to ICJ can be considered in the future.

Question Five: Batu Puteh Island is located nearer to Johor coas (7.7 nautical miles), much closer than Singapore (25 nautical miles). This poses a question as to why the decision made was not in favour to Malaysia. The distance of within 12 nautical miles between Batu Puteh Island and the Johore coast was not taken into consideration during the trial, eventhough the United Nations Convention on the Law of the Sea (UNCLOS), which is recognised by both Malaysia and Singapore, stated that a nation territorial waters extends up to 12 nautical miles from its baseline. Is Batu Puteh Island located beyond 12 nautical miles from Johore coast? Based on this 12 nautical miles argument, the ICJ decision seemed to be more favourable to Singapore and Malaysia seemed to have no sovereignty over its territorial waters even when Pedra Branca is located just 7.7 nautical miles from its shore. Therefore, will ICJ take into consideration the distance and location when making its judgment in relation to this case?

\section{Implications and Lesson Learnt}

We must be fully aware that today's mistakes will adversely affect our future generations. We must adhere to and act with caution as our initial plan to submit the dispute to the ICJ is to maintain peace and good relations between neighbouring countries.

Malaysians are known to be generous. They easily help others that sometimes certain parties easily take advantages by taking what is rightfully ours instead of being grateful. This is the reality.

The people in general and the Malaysian government in particular have to accept this decision positively and learn from the territorial dispute over Batu Puteh Island so that the sovereignty of the country will continue to be preserved. Everyone knows that the island belongs to Malaysia (specifically Johore) with all related documents are complete and history has proven it. Our absent mindedness led us in losing the island sovereignty to other nation. The negligence of former administrators, who allowed Singapore to exercise authority over the lighthouse and the island, had cost us the ownership of the island. Moreover, without thinking long and far, we just instantly confirmed that Johore did not claim ownership of the island though the confirmation was made by black and white document only. The implication will be worse if these weaknesses are exploited by leading nations with hidden agenda. Everything has been sculpted in history, similar to when we lost Temasik to British (later known as Singapore).

Ironically, we did nothing but making claims as if it is a historical tradition. However, Singapore had carried out as much efforts, commitments, expenses and so on when making the claims as they did with the island development. The decision was in favour to Singapore as they gained the advantages of carrying out various acts of sovereignty in respect of the island and this was allowed by Malaysia. Therefore, they succeed in this claim over their capacity to administer the island for long.

Singapore backed its claims to the legal occupation by the British when they built Hosburgh Lighthouse on Batu Puteh Island. They also raised the failure of Malaysia to produce a permission letter given by the Johore government to the British. Subsequently, Singapore also submitted evidences to demonstrate administrative and statutory authority on Batu Puteh Island, and the activities done on the island such as access, control, equipment and others. Singapore argued that Malaysia did not exercise any administrative and law enforcement activities on Batu Puteh Island and has never responded to these activities performed by Singapore on the island. In addition, Singapore asserted that the letter by the Acting
Secretary of Johor which stated that Johore did not claim Pedra Branca ownership was the basis of this judgment. Although Johore held the original ownership before 1953, the letter had denied the rights over the island altogether (6).

Something can be learnt from the weaknesses in terms of the administration and the letter by the Acting Secretary of Johor in 1953. Historically, Batu Puteh Island and the surrounding islets belonged to Johore government. ICJ acknowledged the rights based on Agreement 1819, Agreement March 1824, Agreement August 1824, Agreement 1927 and et cetera. However, when asked by Singapore about the status of the island, the Johore government responded that the island was no longer belonged to the state. The letter strengthened the argument made in the court that by 1953 , Johore sovereignty over the island had been passed over to Singapore (4).

Nevertheless, the final judgment was deemed to be a blessing in disguise. Malaysia may lose its sovereignty over Batu Puteh Island, but it has won the rights as a sovereign over Middle Rocks. This allows Johore fisherman to catch fish around the area which was previously a non grata for Malaysian fishermen. Indirectly, this acknowledges Malaysia rights over Middle Rocks and the nearby area (4).

The situation was still in favour to Malaysia $(15-1)$ since the 'whole' Batu Puteh Island and the surrounding areas were not passed on to Singapore. This is indeed a blessing as Malaysia was able to claim its right on the other maritime features around Batu Puteh Island. The decision was unexpected because the whole situation had been directed a total loss over the islands. Hence, Malaysians and the Malaysian government need to accept the decision positively and learn from this experience so that the sovereignty of our nation can be kept.

ICJ judgment gives Malaysia more benefits in the sense that Singapore has lost its status quo, especially with regards to the Middle Rocks. In addition, if the United Nations Convention on the Law of the Sea (UNCLOS) is being used, the South Ledge should belong to Malaysia based on the maritime delimitation of about 0.6 nautical miles from Middle Rocks. The decision granted Middle Rocks sovereignty to Malaysia, which can be seen breaking Singapore monopoly in the island nearby waters since it now has a neighbour, separated with only 0.6 nautical miles. Though the former Prime Minister of Malaysia, Tun Abdullah Ahmad Badawi, was saddened, he perceived the situation as a win-win situation when Malaysia was given the sovereignty over Middle Rocks while South Ledge was subjected to the state in the territorial waters of which it is located. It can be said that 'we are winning though not entirely winning, we may be losing but not entirely defeated' (4).

\section{Conclusion}

The most important lesson of this judgment decision is to learn from history and remember that history repeats itself in the future. Our own mistakes cost us an island which originally ours for centuries. Always be careful when making any decisions or be sorry for life. Learn from Tun Hussein Onn's experience and philosophy. He said that, "It is better to be safe now than to be sorry later". He usually took his time and cautious when making any decisions (7). His careful, meticulous, disciplined, silent and unique personality played a significant role in handling various issues that may affect national security and future.

For Malaysia, the dispute over Batu Puteh Island with Singapore has brought upon a great lesson and a great deal of impact to the country especially on the issue of sovereignty. According to ICJ decisions, Malaysia has lost its sovereignty over the island. The failure of Malaysia to provide strong evidences of the island ownership and negligence of former national leaders were the main contributors for the defeat. History does nothing but repeats itself if the younger generation do not learn from history; ignoring it or underestimating the issue of sovereignty. From the case of Batu Puteh Island dispute, it shows that a nation territory can change and get smaller, and this eventually affects national economic 
growth when sovereignty is not defended. As a result, all parties must work hand in hand to find the solution to defend national sovereignty to avoid it from being colonised which undermines the country status, position, image and dignity.

\section{References}

[1] Mohamad M. Islam and the Muslim Ummah: Pelanduk Publications (M) Sdn Bhd; 2000.

[2] Ahmad Esa ea. Ikhtisar Sejarah Pembangunan Malaysia. Johor Bahru: Institut Teknologi Tun Hussein Onn/Muapakat Jaya: 2000.

[3] Carr EH. The Comintern and the Spanish Civil War: Pantheon books; 1984.

[4] Harian B. Jangan Sampai Kesal Kerana Masalah Famili. December; 2008.

[5] Harian B. Kesedaran keselamatan pekerja meningkat. 2007.

[6] Hasan T. Harian Sinar Indonesia Baru (SIB). Kerusakan Hutan Bakau di Sumut Mencapai 62, 7 persen dari luas 83550 Ha. 2007.

[7] Morais JV. Hussein Onn: a tryst with destiny: Times Books International; 1981. 